\title{
Decreased susceptibility of differentiated PC12 cells to oxidative challenge: relationship to cellular redox and expression of apoptotic protease activator factor-1
}

\author{
O Ekshyyan ${ }^{1}$ and TY Aw ${ }^{*, 1}$ \\ 1 Department of Molecular and Cellular Physiology, Louisiana State University \\ Health Sciences Center, Shreveport, LA 71130-3932, USA \\ * Corresponding author: TY Aw, Department of Molecular and Cellular \\ Physiology, LSU Health Sciences Center, 1501 Kings Highway, Shreveport, \\ LA 71130-3932, USA.Tel: + 318-675-6032; \\ Fax: + 318-675-4217;E-mail: taw@Isuhsc.edu
}

Received 31.5.04; revised 17.3.05; accepted 23.3.05; published online 06.5.05 Edited by A Finazzi-Agro

\begin{abstract}
We previously showed that tert-butyl hydroperoxide (TBH) induced apoptosis in naïve rat pheochromocytoma (nPC12) cells that correlated with cellular redox imbalance and mitochondrial apoptotic signaling. In this study, we tested the hypothesis that differentiation of $\mathrm{nPC} 12$ cells results in altered susceptibility to TBH utilizing a model of differentiated PC12 (dPC12) cells induced by nerve growth factor. TBH $(100 \mu \mathrm{M})$ induced $\mathrm{dPC} 12$ apoptosis $(12 \%$ at $24 \mathrm{~h})$ at levels lower than naïve cells (35\%). This resistance was associated with elevated GSH, NADPH (reduced nicotinamide adenine dinucleotide phosphate), TBH metabolism, redox enzyme activities, reduced cellular GSH/GSSG (glutathione disulfide) status and preservation of mitochondrial membrane potential. Altering cellular GSH with ethacrynic acid or $\mathrm{N}$-acetylcysteine, respectively, exacerbated or protected against $\mathrm{dPC} 12$ apoptosis. $\mathrm{dPC} 12$ apoptosis was mediated by caspase- 9 and -3 activation and apoptosis protease activator protein-1 (Apaf-1) expression. These results show that $\mathrm{nPC} 12$ transition to $\mathrm{dPC} 12$ cells afforded protection against oxidative challenge due to maintenance of reduced GSH/GSSG and decreased Apaf-1 expression.

Cell Death and Differentiation (2005) 12, 1066-1077. doi:10.1038/sj.cdd.4401650; published online 6 May 2005
\end{abstract}

Keywords: PC12 cell apoptosis; differentiation; nerve growth factor; GSH redox imbalance; mitochondrial apoptosis signaling; apoptosis protease activator factor-1

\footnotetext{
Abbreviations: $\mathrm{PC} 12$, pheochromocytoma cells; $\mathrm{nPC12}$, naïve PC12; dPC12, differentiated PC12; NGF, nerve growth factor; $\mathrm{TBH}$, tert-butyl hydroperoxide; TNF $\alpha$, tumor necrosis factoralpha; NAC, $N$-acetylcysteine; EA, ethacrynic acid; ROS, reactive oxygen species; GSH, reduced glutathione; GSSG, glutathione disulfide; DAPI, 4',6-diamidino-2-phenylindole; F12 K, Kaighn's modification of Ham's F-12; HPLC, high-performance liquid chromatography; PBS, phosphate-buffered saline; TCA, trichloroacetic acid; IETD-CHO, [acetyl-alanine-alanine-valine-alanine-
}

leucine-leucine-proline-alanine-valine-leucine-leucine-alanineleucine-leucine-alanine-proline-isoleucine-glutamate-threonineaspartate-CHO]; LEHD-CHO, [acetyl-alanine-alanine-valinealanine-leucine-leucine-proline-alanine-valine-leucine-leucine-alanine-leucine-leucine-alanine-proline-leucine-histidine-aspartate$\mathrm{CHO}$; $\mathrm{NADH}$, reduced nicotinamide adenine dinucleotide; $\mathrm{NADPH}$, reduced nicotinamide adenine dinucleotide phosphate; Apaf-1, apoptosis protease activator factor-1; JC-1, 5, 5',6, $6^{\prime}$ tetrachloro-1, 1' ${ }^{\prime}, 3,3^{\prime}$-tetraethyl-benzamidazolocarbocyanin iodide; $\mathrm{PI}$, propidium iodide

\section{Introduction}

The fate of a cell is determined by a balance of survival or promoting signals. While survival signals mediate cell maintenance, promoting signals induce cells to proliferate, differentiate, transform or apoptose. ${ }^{1,2}$ In recent years, studies from our laboratory have demonstrated that imposition of mild oxidative stress or redox shifts can induce transition of cells from quiescent to proliferative, growth arrested or apoptotic states in a variety of intestinal cell lines wherein specific cell transitions was dictated by the duration and extent of redox imbalance..$^{3-8}$ Notably, we found that an early loss of the glutathione-to-glutathione disulfide (GSH-toGSSG) redox balance is critical to the signaling of cell transition to apoptosis. In other studies, we demonstrated that treatment of a rat adrenal medullary pheochromocytoma (PC12) cell line with tert-butyl hydroperoxide (TBH) or the GSH oxidant, diamide, induced cell apoptosis that directly correlated with an early loss of cellular GSH/GSSG imbalance, which initiated the cellular apoptotic cascade. ${ }^{9,10}$ Collectively, these findings suggest that the loss of cellular redox homeostasis is a key upstream event that mediates mitochondrial apoptotic signaling during oxidative challenge, and that this early redox signaling could be a general paradigm of apoptotic induction in a variety of cell types.

The PC12 cell model was first characterized in 1976 by Greene and Tischler ${ }^{11}$ and has since been used as a model to study the cellular and molecular aspects of neuronal apoptosis. A notable characteristic of PC12 cells is that they can readily be induced to differentiate in culture with the neurotrophic factor, nerve growth factor (NGF) whereby cells cease to multiply, assume a neurite-bearing phenotype that resemble mature sympathetic neurons and exhibit firm attachment to the substratum. ${ }^{11}$ Current evidence in the literature supports a cytoprotective role of NGF in PC12 cells such as against apoptosis induced by hydrogen peroxide ${ }^{12}$ and tumor necrosis factor-alpha (TNF $\alpha){ }^{13}$ The protective effect of NGF has been suggested to be related to the upregulation of heme oxygenase- $1^{14}$ and antioxidant enzymes such as GSH peroxidase and catalase,${ }^{15}$ modulation 
of GSH metabolism ${ }^{16-18}$ or suppression of caspase activities. ${ }^{13,19}$ Moreover, Vyas et al. ${ }^{20}$ recently demonstrated that differentiated PC12 (dPC12) cells exhibited less sensitivity to cytochrome $c$-induced apoptosis that was associated with increased mitochondrial release of inhibitory apoptotic proteins and decreased postmitochondrial activation of caspase-9, consistent with a differentiation-dependent sensitivity to apoptogenic factors. Based on these findings, one would predict that $\mathrm{dPC} 12$ cells would be less susceptible to oxidative injury, but the literature evidence is equivocal. The support for the notion of decreased oxidant-induced cell vulnerability comes from studies of Sung et al. ${ }^{21}$ who demonstrated that differentiated neuron-like PC12 cells are more resistant to hydrogen peroxide than undifferentiated proliferating PC12 cells. Other investigators have shown that differentiated neuron-like PC12 cells are more sensitive to degenerative stressors such as TNF $\alpha$ and reactive oxygen species (ROS)like hydroperoxides. ${ }^{22,23}$ Thus, the prevailing view of decreased vulnerability of the differentiated phenotype to the effects of oxidative and redox stress and apoptotic signaling remains unresolved.

As NGF can readily induce PC12 transition from a naïve, actively proliferating to a quiescent, differentiated phenotype ${ }^{11}$ we used this cell line in the current study to examine $\mathrm{TBH}$-induced susceptibility between the two cell transition stages, and to define the determinants of this difference. Moreover, since our recent results implicate a decrease in the GSH-to-GSSG redox as a critical event in the initiation of apoptosis in naïve PC12 (nPC12) cells caused by the oxidant, $9,10,24$ the contribution of cellular GSH/GSSG redox to $\mathrm{TBH}$-induced apoptosis in $\mathrm{dPC} 12$ cells was examined. Given that the mitochondria is pivotal to the initiation of the apoptotic cascade mediated by oxidative stress and redox imbalance in nPC12 cells, we further investigated mitochondrial involvement in the apoptotic process in $\mathrm{dPC} 12$ cells.

\section{Results}

\section{Differential susceptibility of nPC12 and dPC12 cells to TBH treatment: relationship to cellular GSH homeostasis and TBH metabolism}

Figure 1a compares the results on the effect of $100 \mu \mathrm{M} \mathrm{TBH}$ on apoptosis of $\mathrm{nPC} 12$ and $\mathrm{dPC} 12$ cells. Baseline apoptosis was approximately $3-4 \%$ in both cell lines. $\mathrm{TBH}$ treatment induced a $35 \%$ apoptosis in $\mathrm{nPC} 12$ cells, in agreement with our previous findings. ${ }^{9}$ In contrast, $100 \mu \mathrm{M}$ TBH caused $12 \%$ apoptosis in $\mathrm{dPC} 12$, indicating that these cells are relatively more resistant to oxidative injury. To investigate the determinants of this oxidant resistance in $\mathrm{dPC} 12$ cells, we examined the cellular redox status, GSH-dependent redox cycle enzyme activities and the ability to detoxify $\mathrm{TBH}$. The results in Figure 1b show that $\mathrm{dPC} 12$ as compared to $\mathrm{nPC} 12$ cells exhibited higher activities of the three enzymes critical to maintaining the $\mathrm{GSH}$ redox cycle function, namely, $\mathrm{GSH}$ peroxidase, GSSG reductase and glucose 6-phosphate dehydrogenase. Total GSH concentrations as well as those in the cytoplasmic and mitochondrial compartments were higher in $\mathrm{dPC} 12$ cells (Figure 2a). Interestingly, while total cellular and cytoplasmic GSSG levels were not different, a
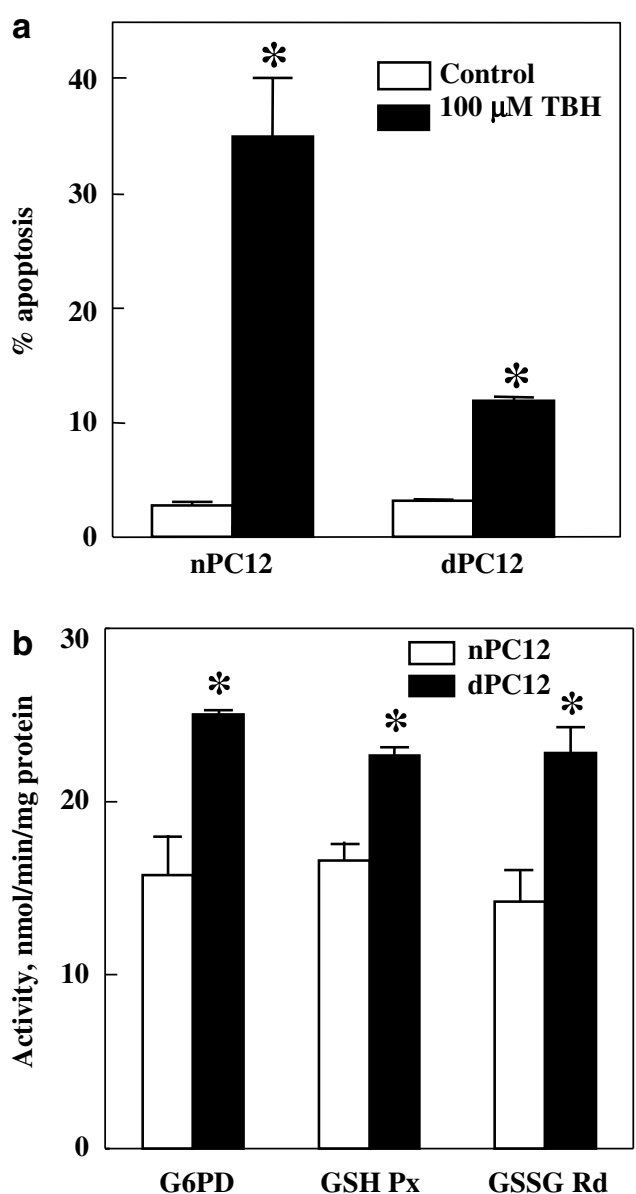

Figure 1 TBH-induced apoptosis and activities of redox cycle enzymes in $\mathrm{nPC} 12$ and $\mathrm{dPC} 12$ cells. (a) PC12 cells were treated for $24 \mathrm{~h}$ with $100 \mu \mathrm{M} \mathrm{TBH}$ and apoptosis was determined by DAPI staining as described in Materials and Methods. Results are expressed as mean \pm S.E. for five separate experiments. ${ }^{\star} P<0.05$ versus corresponding values for controls. (b) Cellular extracts were prepared from $\mathrm{PC} 12$ cells and activities of glucose-6-phosphate dehydrogenase (G6PD), GSH peroxidase (GSH Px) and GSSG reductase (GSSG Rd) were determined spectrophotometrically by enzyme coupled assays. Enzyme activities are expressed as nmol/min/mg protein and presented as mean + S.E. for three separate experiments. ${ }^{*} P<0.05$ versus corresponding values for $\mathrm{nPC12}$ cells

significantly greater mitochondrial GSSG pool was observed in $\mathrm{dPC} 12$ cells (Figure 2b). Notwithstanding, the overall cytoplasmic and mitochondrial GSH-to-GSSG redox status were more reduced in $\mathrm{dPC} 12$ cells (Figure $2 \mathrm{c}$ ). In parallel with the GSH/GSSG redox status, higher levels of the pyridine nucleotide reductants (NADH (nicotinamide adenine dinucleotide) and NADPH (nicotine adenine dinucleotide phosphate)) were found in $\mathrm{dPC} 12$ cells (Figure 3a). There was no significant difference between baseline concentrations of $\mathrm{NADH}$ and NADPH and those after TBH treatment in $\mathrm{dPC} 12$ cells (Figure $3 \mathrm{a}$ ), suggesting an adequate reductant supply during $\mathrm{TBH}$ catabolism. The kinetic data in Figure $3 \mathrm{~b}$ show that $\mathrm{TBH}$ was metabolized more rapidly in $\mathrm{dPC} 12$ than in $\mathrm{nPC} 12$ cells. The rate of TBH elimination was $3.8 \pm 0.1 \mathrm{nmol} /$ $10^{6} \mathrm{cells} / \mathrm{min}$ for $\mathrm{nPC} 12$ cells and $4.4 \pm 0.1 \mathrm{nmol} / 10^{6} \mathrm{cells} / \mathrm{min}$ for dPC12 cells $(P<0.001)$. By $30 \mathrm{~min}$, the TBH concentrations in the incubation media were $10.3 \pm 1.1 \mu \mathrm{M} \mathrm{TBH}$ for $\mathrm{nPC} 12$ cells and $3.3 \pm 0.9 \mu \mathrm{M}$ TBH for dPC12. Taken together, 
a
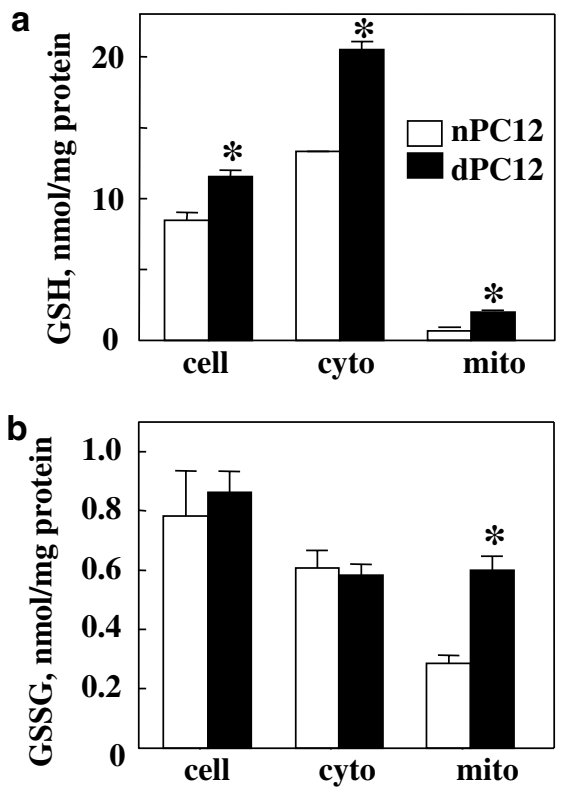

C

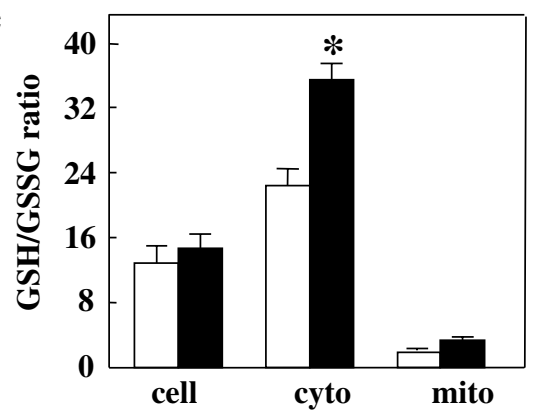

Figure 2 GSH/GSSG status in $\mathrm{nPC1}$ and $\mathrm{dPC} 12$ cells and in mitochondria and cytoplasmic compartments. Total cell extracts (from $2 \times 10^{6}$ cells) as well as the cytoplasmic and mitochondrial fractions were treated with 5\% TCA to remove proteins and the acid supernatants were derivatized for GSH/GSSG analyses by HPLC. The mitochondrial and cytoplasmic compartments were obtained by digitonin fractionation. Concentrations of GSH and GSSG are expressed as nmol/mg protein. (a) GSH; (b) GSSG; and (c) GSH-to-GSSG ratio. Cell, total cellular content; cyto, cytoplasmic content; mito, mitochondrial content. Results are presented as mean \pm S.E. for three separate experiments. ${ }^{*} P<0.05$ versus corresponding values for $\mathrm{nPC} 12$ cells

these results indicate that differentiation of $\mathrm{PC} 12$ cells results in the establishment of a highly reduced intracellular environment and an elevated capacity for reduction of GSSG, elimination of TBH and maintenance of GSH homeostasis, characteristics that contributed to decreased susceptibility to oxidative challenge in these cells. The results further implicate a role for cellular redox in mediating $\mathrm{TBH}$-induced cell apoptosis in dPC12 cells.

As NADPH oxidation and depletion is temporally linked to the dissipation of the mitochondrial transmembrane potential, $\Delta \psi_{\mathrm{m}},{ }^{25}$ we determined $\Delta \psi_{\mathrm{m}}$ in $\mathrm{nPC} 12$ and $\mathrm{dPC} 12$ cells treated with $100 \mu \mathrm{M} \mathrm{TBH}$ using the fluorescent cationic dye, 5,5',6, $6^{\prime}$-tetrachloro-1,1',3,3'-tetraethyl-benzamidazolocarbocyanin iodide (JC-1) and flow cytometry. The results are illustrated in Figure 4. The $\mathrm{R} 2$ and $\mathrm{R} 3$ regions represent cells that exhibited high and low red-to-green fluorescence ratio, representing
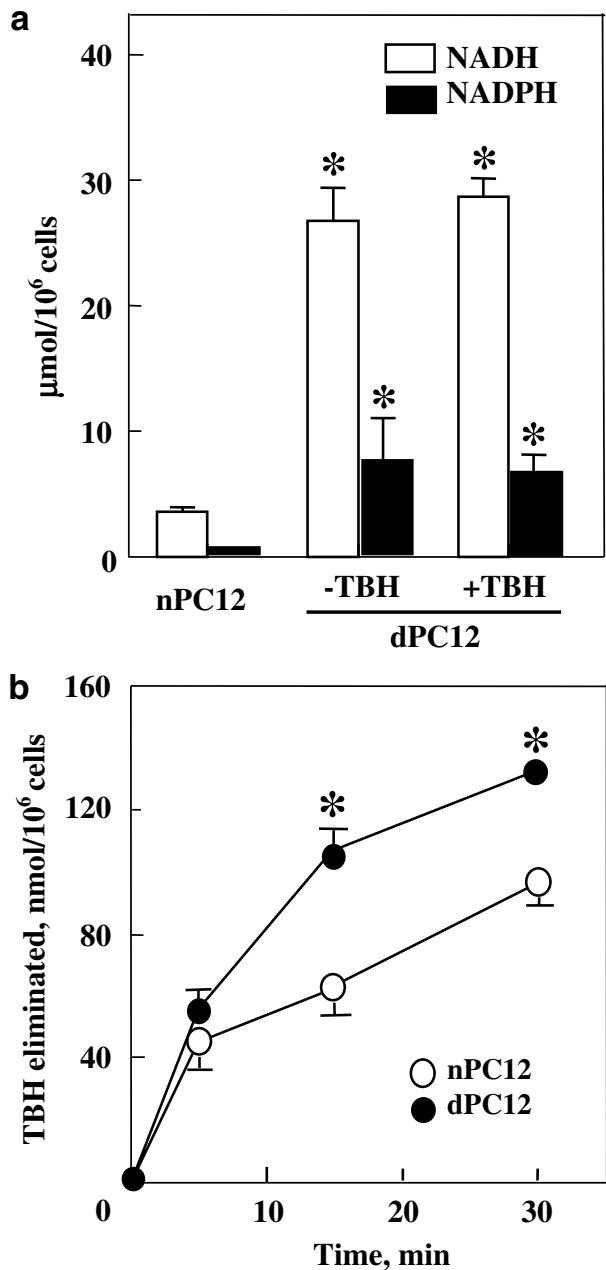

Figure 3 Cellular NADH and NADPH and kinetics of TBH elimination in $\mathrm{nPC12}$ and $\mathrm{dPC} 12$ cells. (a) Total cell extracts were prepared from $\mathrm{nPC} 12$ and $\mathrm{dPC} 12$ cells $\left(4 \times 10^{6} / \mathrm{ml}\right)$ and baseline concentrations of NADH and NADPH were determined spectrophotometrically. In some experiments, dPC12 cells were treated with $100 \mu \mathrm{M} \mathrm{TBH}$ for $30 \mathrm{~min}$, and thereafter, NADH and NADPH were determined. Cellular concentrations of NADH and NADPH are expressed as $\mu \mathrm{mol} / 10^{6}$ cells and presented as mean \pm S.E. for three separate experiments. ${ }^{\star} P<0.05$ versus corresponding values for $\mathrm{nPC} 12$ cells. (b) $\mathrm{nPC} 12$ and $\mathrm{dPC} 12$ cells were treated with $100 \mu \mathrm{M} \mathrm{TBH}$, and at time points $0,5,15$ and $30 \mathrm{~min}$, incubation media were sampled for determination of TBH concentrations. The amount of TBH metabolized is expressed as nmol/ $10^{6}$ cells and presented as mean \pm S.E. for six separate experiments. ${ }^{*} P<0.05$ versus corresponding values for $\mathrm{nPC1} 12$ cells

high and low $\Delta \psi_{m}$, respectively. Typically, $10-13 \%$ of untreated $\mathrm{nPC} 12$ or dPC12 cells exhibited decreased $\Delta \psi_{\mathrm{m}}$. Treatment of $\mathrm{nPC12}$ with $\mathrm{TBH}$ caused a time-dependent increase in the percentage of cells exhibiting decreased redto-green fluorescence ratio, consistent with a significant loss of $\Delta \psi_{\mathrm{m}}$ associated with $\mathrm{TBH}$ exposure. In contrast, the percentage of $\mathrm{TBH}$-treated $\mathrm{dPC} 12$ cells exhibiting low redto-green fluorescence ratio was essentially unchanged from controls over $1 \mathrm{~h}$, indicative of $\Delta \psi_{\mathrm{m}}$ preservation.

Since $\mathrm{TBH}$ can induce a necrotic phenotype in addition to classical apoptosis, we examined the contribution of apoptosis and necrosis in $\mathrm{nPC} 12$ and $\mathrm{dPC} 12$ cells by flow cytometry using double staining of cells with YO-PRO-1 and propidium 

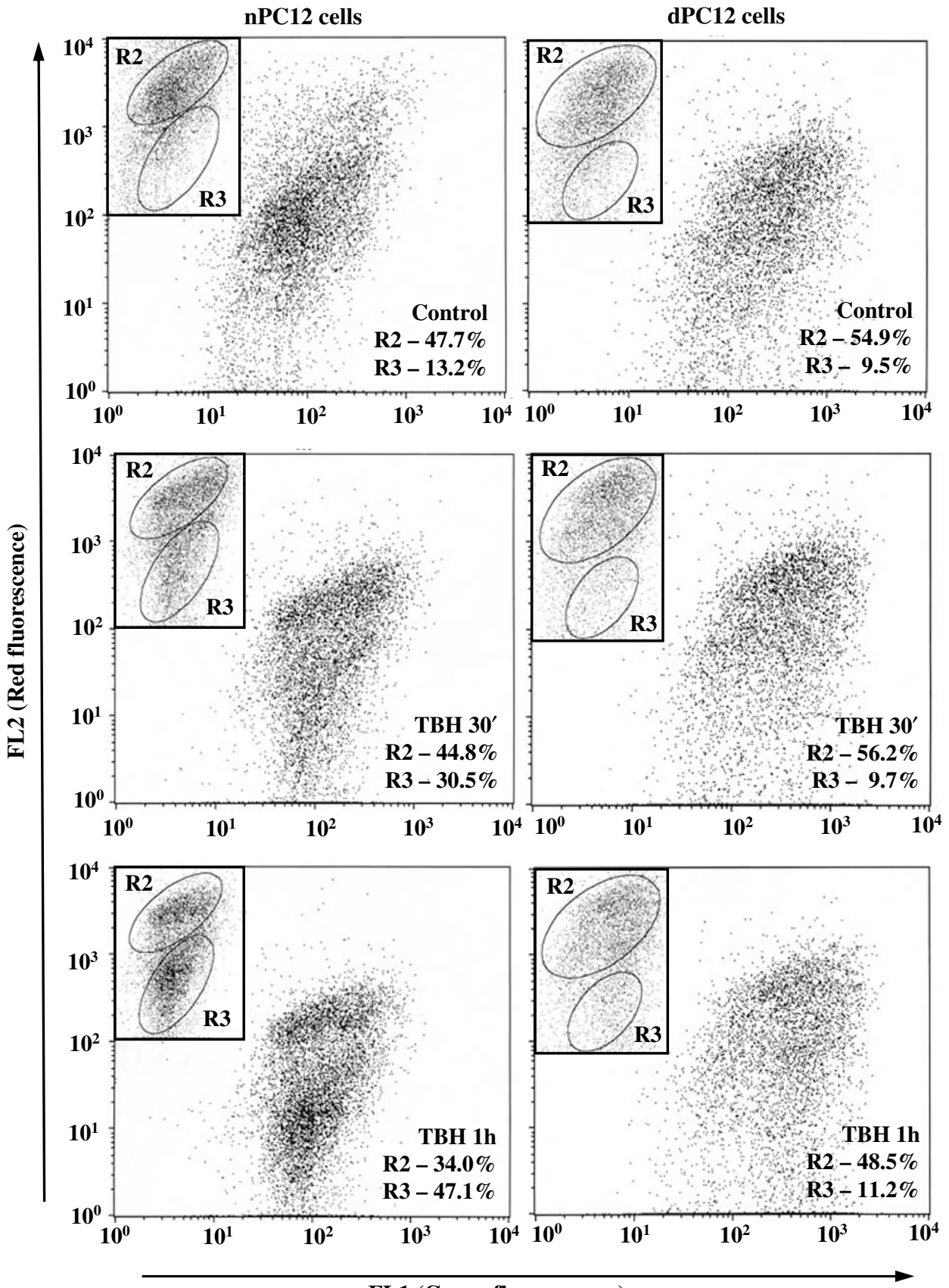

FL1 (Green fluorescence)

Figure 4 Flow cytometry analyses of mitochondrial membrane potential $\Delta \psi_{\mathrm{m}}$ in TBH-treated PC12 cells by JC- 1 fluorescence. Changes in $\Delta \psi_{\mathrm{m}}$ were detected using the fluorescent cationic dye JC-1 as described in Materials and Methods. Briefly, PC12 cells were treated with $100 \mu \mathrm{M} \mathrm{TBH}$ for $30 \mathrm{~min}$ and $1 \mathrm{~h}$, incubated with $5 \mu \mathrm{g} / \mathrm{ml}$ JC-1 for 15 min and processed for flow cytometry. The inset shows delineated R2 and R3 regions that represent cell populations exhibiting high (R2) or low (R3) red-togreen fluorescence ratio, consistent with high and low $\Delta \psi_{\mathrm{m}}$, respectively. Results shown are one representative of three separate experiments

iodide (PI). In cells stained with either dye alone, we found that a greater percentage of $\mathrm{nPC} 12$ cells exhibited permeability to $\mathrm{PI}$ and YO-PRO-1 following TBH exposure (Figure 5a), indicating that $\mathrm{nPC} 12$ cells were more susceptible than dPC12 cells to TBH. PC12 cells double stained with YOPRO-1 and PI exhibited an uncharacteristic 'elliptical' fluorescence distribution (Figure $5 \mathrm{~b}$ ). In controls, $26 \%$ of nPC12 and $38 \%$ of $\mathrm{dPC} 12$ cells were already YO-PRO-1 positive or
YO-PRO-1 and PI positive, indicating substantial apoptosis that were significantly higher than cells stained with $4^{\prime}, 6$ diamidino-2-phenylindole (DAPI) on coverslips (average baseline apoptosis of 3-4\%). At 2-6h, the flow cytometry histograms of cells treated with TBH exhibited varying extents of $\mathrm{YO}-\mathrm{PRO}-1^{-} / \mathrm{PI}^{-}, \mathrm{YO}-\mathrm{PRO}-1^{+} / \mathrm{PI}^{-}, \mathrm{YO}-\mathrm{PRO}-1^{+} / \mathrm{PI}^{+}$and $\mathrm{YO}-\mathrm{PRO}-1^{-} / \mathrm{PI}^{+}$, which we have designated as viable, early apoptosis, late apoptosis with contributions from secondary 
a

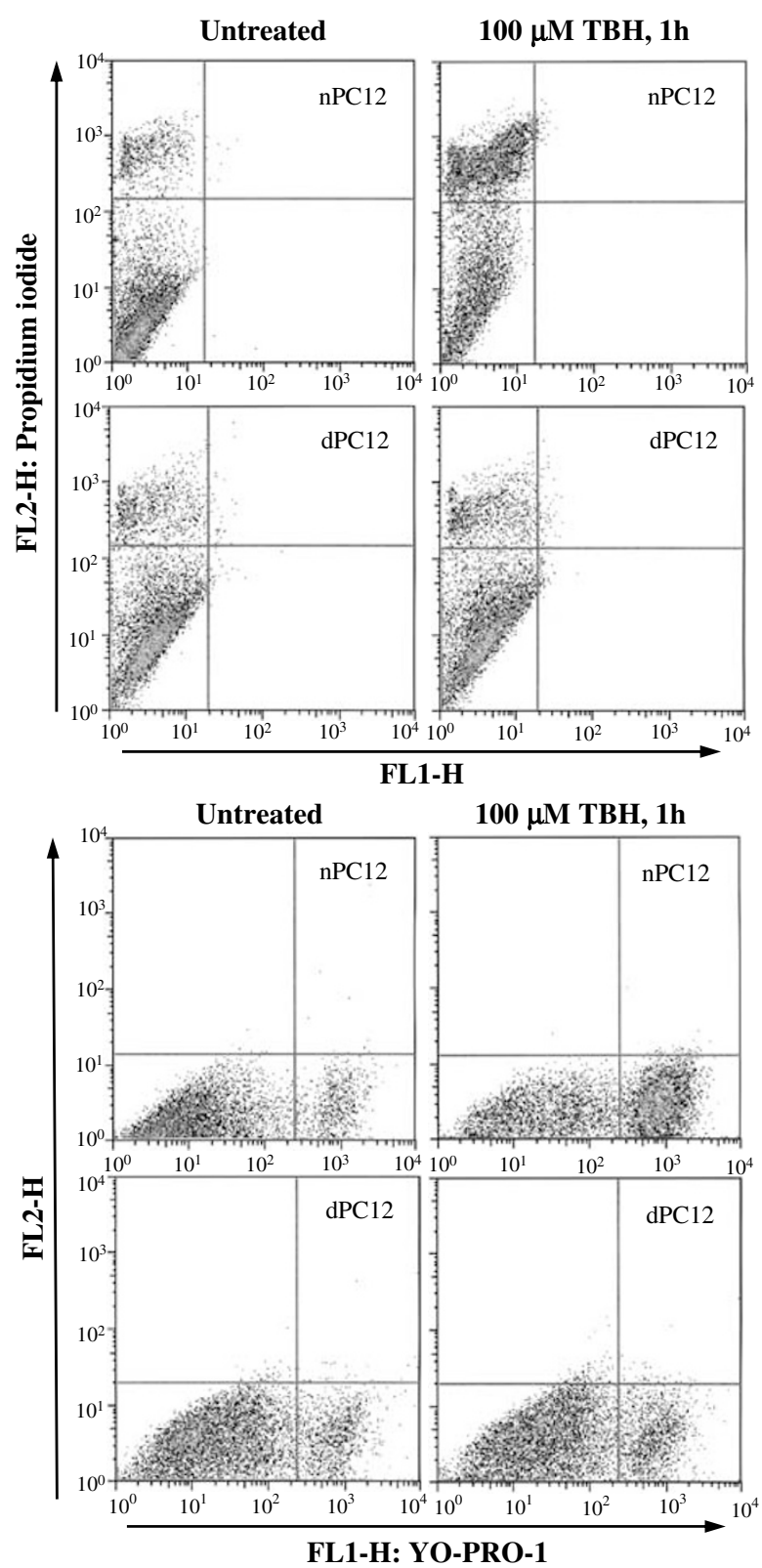

b
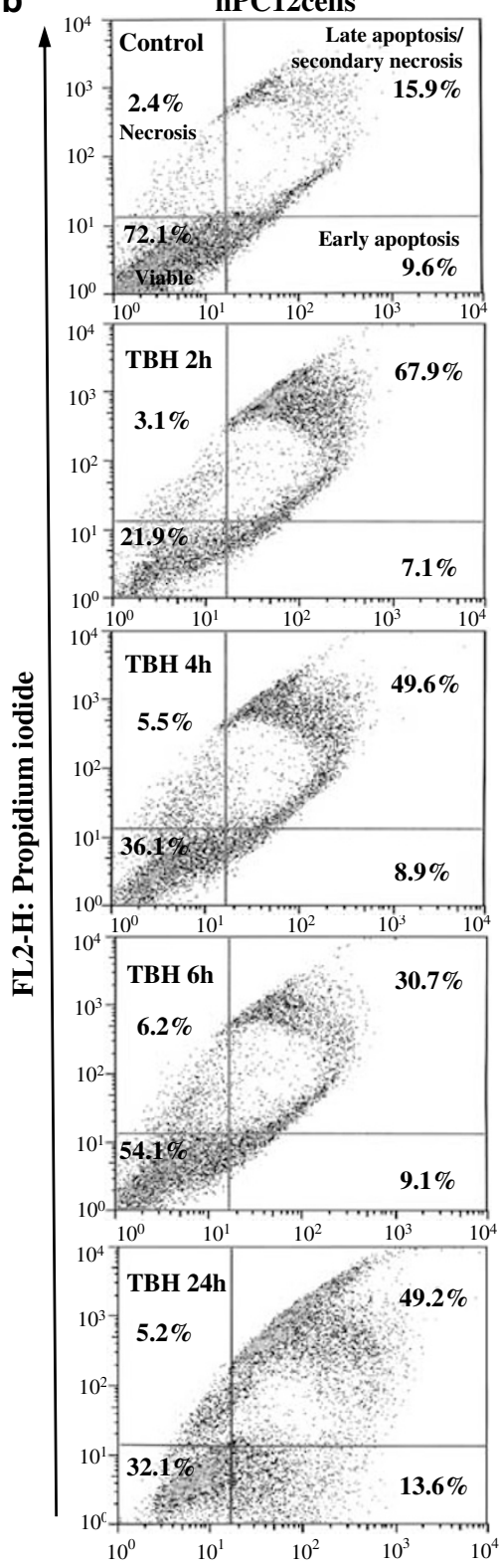
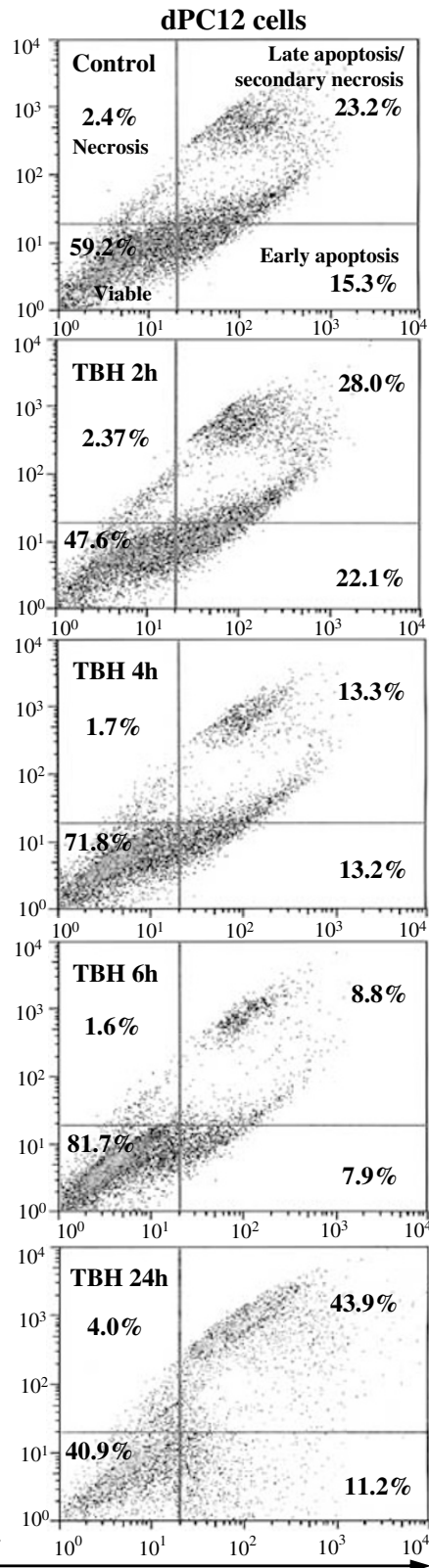

FL1-H: YO-PRO-1

Figure 5 Flow cytometry analyses of TBH-induced cell death in nPC12 and dPC12 cells double stained with YO-PRO-1 and PI. nPC12 and dPC12 cells were treated with $100 \mu \mathrm{M}$ TBH for 2-24h, stained with either PI or YO-PRO-1 individually (5A) or combined YO-PRO-1/PI (5B), and processed for flow cytometry. Cell percentages representing viable $\left(\mathrm{YO}-\mathrm{PRO}^{-} \mathrm{PI}^{-}\right)$, early apoptosis $\left(\mathrm{YO}-\mathrm{PRO}{ }^{+} \mathrm{PI}^{-}\right)$, late apoptosis/secondary necrosis $\left(\mathrm{YO}^{-} \mathrm{PRO}{ }^{+} \mathrm{PI}^{+}\right)$and necrosis $\left(\mathrm{YO}^{-} \mathrm{PRO}{ }^{-} \mathrm{PI}^{+}\right)$are shown for the treatment groups. Results shown are one representative of three separate experiments

necrosis and necrosis, respectively. From $2 \mathrm{~h}$, TBH induced greater death of $\mathrm{nPC} 12$ than $\mathrm{dPC} 12$ cells, consistent with enhanced sensitivity of $\mathrm{nPC} 12$ cells to $\mathrm{TBH}$ challenge. At these times, late apoptotic and/or secondary necrotic cells accounted for the majority of the nonviable cell population of nPC12 cells $(60-80 \%)$, while apoptotic dPC12 cells were about equally split between early apoptosis and late apoptosis/secondary necrosis. Interestingly, over this duration, we consistently observe a temporal decrease in the percent of nonviable cells in both $\mathrm{nPC} 12$ and $\mathrm{dPC} 12$ cells, which we attribute to a disproportionate loss of nonviable cells and greater recovery of viable cells during processing of cells exposed to longer TBH treatment. This suggestion was supported by direct cell counting of viable and nonviable cells taken at these different processing stages (data not shown). At $24 \mathrm{~h}, \sim 70-75 \%$ of nonviable $\mathrm{nPC} 12$ and $\mathrm{dPC} 12$ cells are in the late apoptosis/secondary necrosis phase. Similar flow cytometry profiles (2-24h) were also exhibited in $\mathrm{nPC} 12$ and dPC12 cells treated with staurosporine, known to induce cell death exclusively by apoptosis ${ }^{26}$ (data not shown). However, 
at $24 \mathrm{~h}$, while $\mathrm{TBH}$ induced predominantly $\mathrm{YO}-\mathrm{PRO}-1^{+} / \mathrm{PI}^{+}$ cells (late apoptosis/secondary necrosis, Figure 5b), staurosporine predominantly induced $\mathrm{YO}-\mathrm{PRO}-1^{-} / \mathrm{PI}^{+}$cells (necrosis).

\section{TBH-induced changes in intracellular GSH/GSSG: effect of ethacrynic acid (EA), diamide and $\mathrm{N}$-acetylcysteine (NAC)}

To explore the role of cellular redox, we measured the changes in cellular GSH and GSSG at different times (5 min$2 \mathrm{~h}$ ) after treatment with $100 \mu \mathrm{M} \mathrm{TBH}$ (Figure 6). TBH caused a rapid and significant decrease in cellular GSH that remained low up to $2 \mathrm{~h}$ (Figure 6a); GSH levels in untreated cells remained constant over $2 \mathrm{~h}$ (data not shown). Cellular GSSG contents were markedly elevated at $5-15 \mathrm{~min}$ and decreased to below control values by $2 \mathrm{~h}$ (Figure $6 \mathrm{~b}$ ). Importantly, the

a
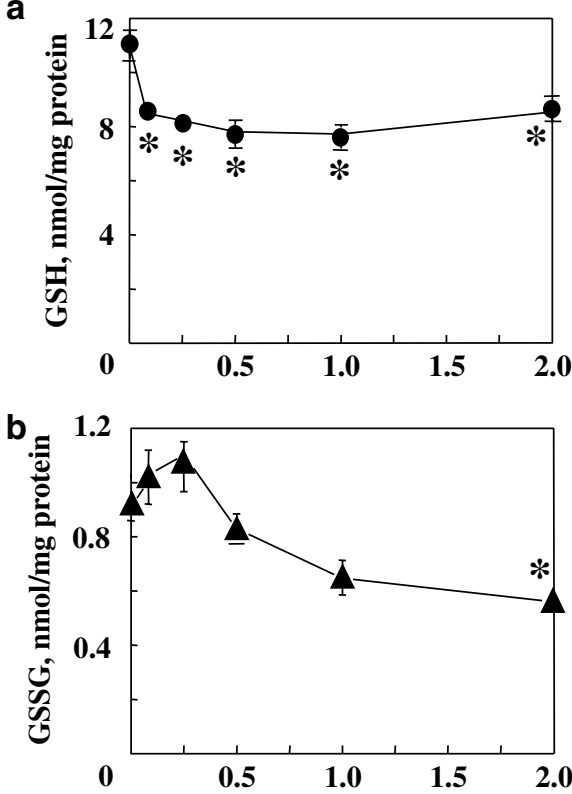

C

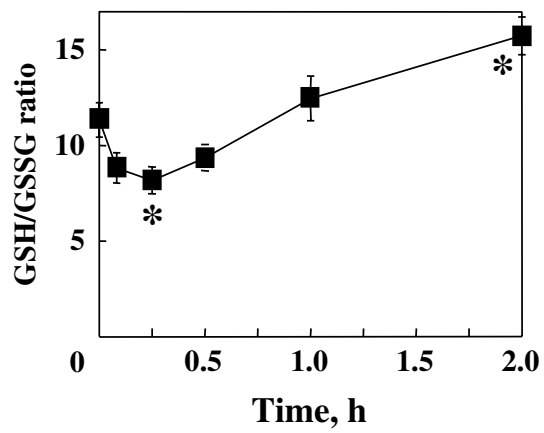

Figure 6 Kinetics of TBH-induced changes in intracellular GSH and GSSG in dPC12 cells. dPC12 cells were treated with $100 \mu \mathrm{M} \mathrm{TBH}$, and at designated times between 0 and $2 \mathrm{~h}$, samples were collected and derivatized for $\mathrm{GSH}$ and GSSG measurements by HPLC. (a) GSH; (b) GSSG; and (c) GSH-to-GSSG ratio. Cellular GSH and GSSG are expressed as $\mathrm{nmol} / \mathrm{mg}$ protein and presented as mean \pm S.E. for three separate experiments. GSH and GSSG levels in untreated controls were, respectively, $12 \mathrm{nmol} / \mathrm{mg}$ protein and $0.9 \mathrm{nmol} / \mathrm{mg}$ protein and did not change over the $2 \mathrm{~h}$ incubation. ${ }^{*} P<0.05$ versus zero time decrease in GSH and concomitant increase in GSSG within $15 \mathrm{~min}$ after $\mathrm{TBH}$ challenge resulted in a significant decrease in the GSH-to-GSSG ratio (Figure $6 \mathrm{c}$ ), consistent with the induction of redox imbalance at this time. The GSH-to-GSSG ratio was restored to baseline levels by $1 \mathrm{~h}$ and increased by $2 \mathrm{~h}$. Pretreatment of $\mathrm{dPC} 12$ cells with NAC, a thiol antioxidant and GSH precursor, protected the cells against $\mathrm{TBH}$-induced apoptosis (Figure 7a). However, NAC addition at $1 \mathrm{~h}$ after TBH exposure and at a time after the induction of redox imbalance at $15 \mathrm{~min}$ did not confer cytoprotection (Figure $7 \mathrm{a}$ ). Treatment of $\mathrm{dPC} 12$ cells with the thiol oxidant, diamide at a dose that does not elicit production of $\mathrm{ROS}^{10}$ resulted in apoptotic death (Figure $7 \mathrm{~b}$ ) that was comparable to that induced by $\mathrm{TBH}$. NAC pretreatment of diamide-treated cells effectively
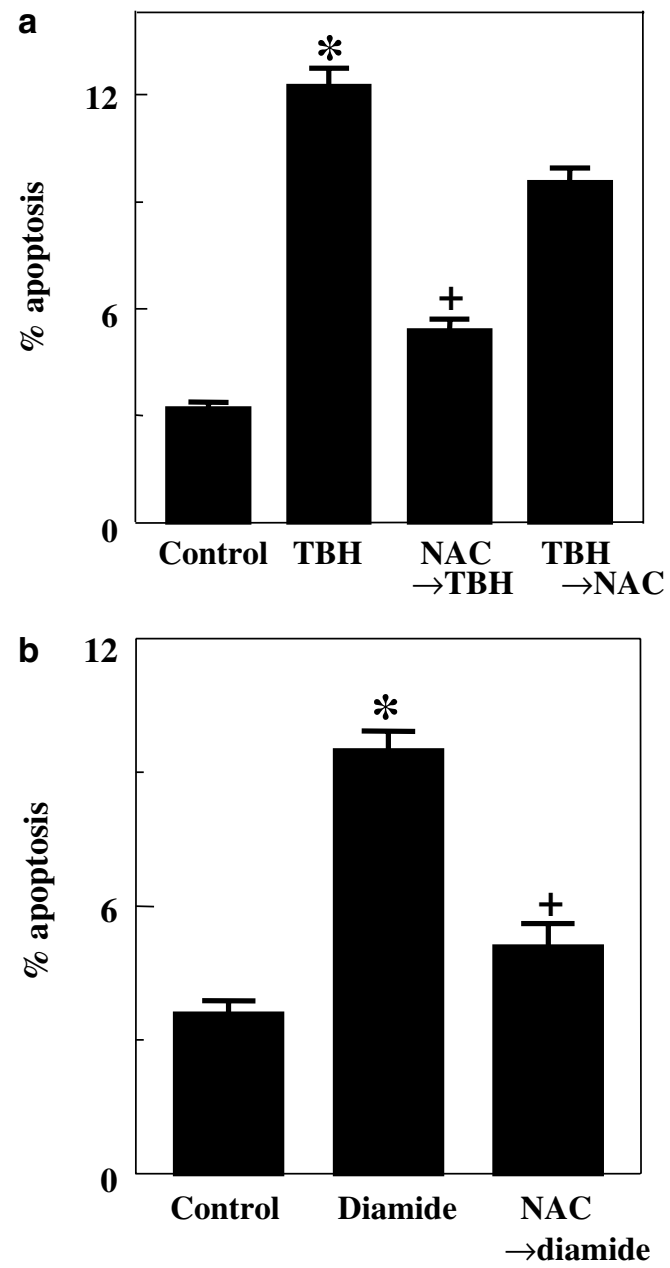

Figure $7 \mathrm{TBH}$ - or diamide-induced apoptosis in $\mathrm{dPC} 12$ cells and attenuation by NAC. (a) dPC12 cells were treated for $24 \mathrm{~h}$ with $100 \mu \mathrm{M}$ TBH and cell apoptosis was determined by DAPI staining. In some experiments, cells were pretreated with $2 \mathrm{mM} N A C$ for $1 \mathrm{~h}$ prior to $\mathrm{TBH}$ treatment $(\mathrm{NAC} \rightarrow \mathrm{TBH})$ or NAC was added to cell incubations at $1 \mathrm{~h}$ after $\mathrm{TBH}$ treatment $(\mathrm{TBH} \rightarrow \mathrm{NAC})$. Results are expressed as mean + S.E. for six separate experiments. ${ }^{*} P<0.05$ versus no TBH control; ${ }^{+} P<0.05$ versus TBH treatment. (b) dPC12 cells were treated for $24 \mathrm{~h}$ with $200 \mu \mathrm{M}$ diamide in the absence or presence of $2 \mathrm{mM} \mathrm{NAC}$ and cell apoptosis was determined by DAPI staining. Results are expressed as mean \pm S.E. for three separate experiments. ${ }^{\star} P<0.05$ versus no diamide control; ${ }^{+} P<0.05$ versus diamide treatment 


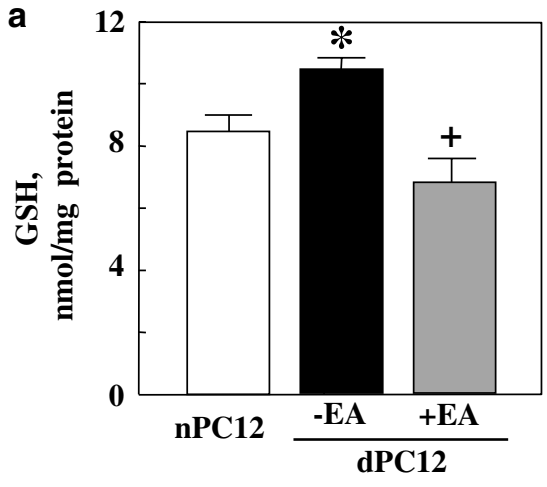

b

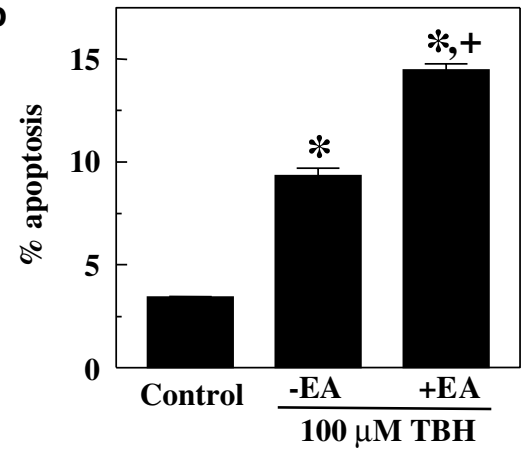

C

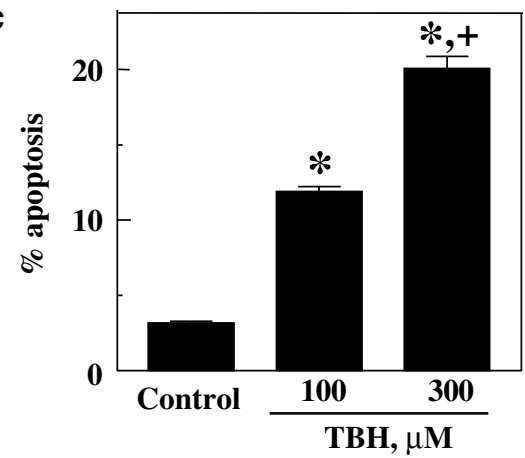

Figure 8 Effect of EA-induced decreased cellular GSH and different TBH concentrations on dPC12 apoptosis. (a) Basal GSH concentrations in $\mathrm{nPC12}$ and $\mathrm{dPC} 12$ cells, as well $\mathrm{dPC} 12$ cells after $1 \mathrm{~h}$ treatment with $20 \mu \mathrm{M} \mathrm{EA}$, were analyzed by HPLC. GSH concentrations are expressed as $\mathrm{nmol} / \mathrm{mg}$ of protein and presented as mean \pm S.E. for three separate experiments. ${ }^{*} P<0.05$ versus nPC12 cells; ${ }^{+} P<0.05$ versus dPC12 minus EA. (b) dPC12 cells were incubated with $100 \mu \mathrm{M}$ TBH without or with EA and cell apoptosis was determined at $8 \mathrm{~h}$. EA was added to cell incubations at $1 \mathrm{~h}$ prior to TBH treatment. Results are expressed as mean + S.E. for three separate experiments. ${ }^{*} P<0.05$ versus no TBH control; ${ }^{+} P<0.05$ versus TBH-treated cells minus EA. (c) $\mathrm{dPC} 12$ cells were treated for $24 \mathrm{~h}$ with 100 or $300 \mu \mathrm{M} \mathrm{TBH}$, and cell apoptosis was determined by DAPI staining. Results are expressed as mean \pm S.E. for three separate experiments. ${ }^{*} P<0.05$ versus no TBH control; ${ }^{+} P<0.05$ versus $100 \mu \mathrm{M} \mathrm{TBH}$

abrogated cell apoptosis (Figure $7 \mathrm{~b}$ ), a response that was similar to that in $\mathrm{TBH}$-treated cells (Figure 7a).

To further investigate the contribution of redox, we treated cells with EA to lower cellular GSH. Figure 8 a shows that cellular GSH contents in naïve cells can be achieved with treatment of dPC12 cells with $20 \mu \mathrm{M}$ EA for $1 \mathrm{~h}$. Accordingly, this decrease in cellular GSH resulted in an exacerbation of $\mathrm{TBH}$-induced cell apoptosis (Figure 8b), consistent with a relationship of dPC12 susceptibility and cellular $\mathrm{GSH}$.
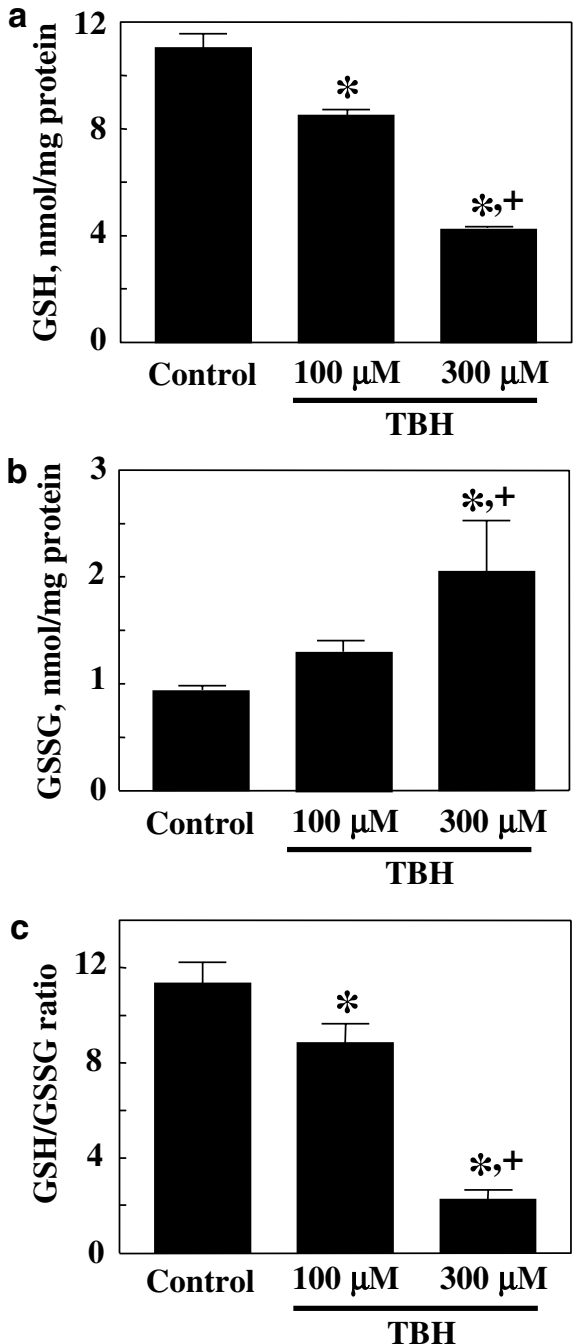

Figure 9 Effect of different TBH concentrations on cellular GSH/GSSG status in $\mathrm{dPC} 12$ cells. $\mathrm{dPC} 12$ cells were treated with either 100 or $300 \mu \mathrm{M} \mathrm{TBH}$, and samples at 0 and 5 min time points were collected and derivatized for GSH and GSSG measurements by HPLC. Cellular GSH and GSSG are expressed as $\mathrm{nmol} / \mathrm{mg}$ protein and presented as mean $+\mathrm{S}$.E. for three separate experiments. (a) GSH; (b) GSSG; and (c) GSH-to-GSSG ratio. ${ }^{*} P<0.05$ versus zero time control; $+P<0.05$ versus $100 \mu \mathrm{M}$ TBH

Figure $8 \mathrm{c}$ shows that $20 \%$ apoptosis of dPC12 cells was observed at $300 \mu \mathrm{M} \mathrm{TBH}$ that was comparable to that after treatment of $\mathrm{nPC} 12$ cells with $100 \mu \mathrm{M} \mathrm{TBH} .{ }^{24}$ Accordingly, a greater magnitude of early decreases in cellular GSH with increases in GSSG and attenuated GSH-to-GSSG ratios were achieved with treatment of cells at $300 \mu \mathrm{M}$ TBH (Figures $9 a-c)$.

TBH-induced dPC12 cell apoptosis is mediated by mitochondrial signals: activation of caspase- 9 and -3 and expression of apoptosis protease activator factor-1 (Apaf-1)

To test whether $\mathrm{TBH}$-induced apoptosis of $\mathrm{dPC} 12$ cells was the result of mitochondria initiated rather than death-receptor initiated signals amplified through the mitochondria, we 
a

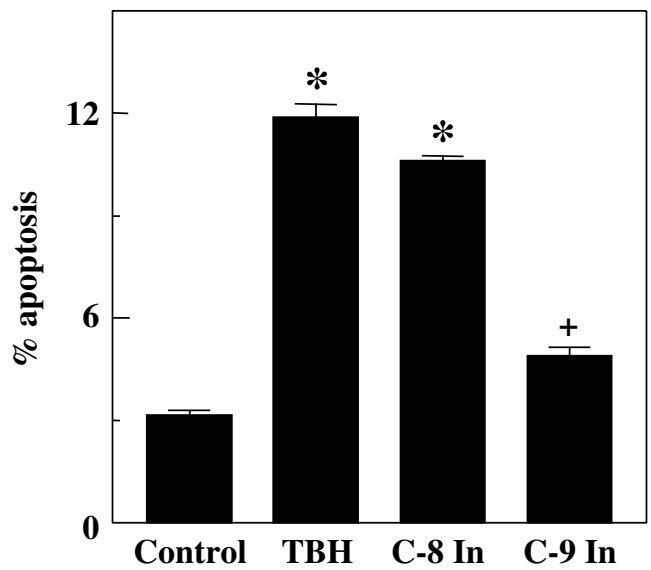

b

$\frac{\text { Naïve Differentiated }}{0 \mathrm{~h} 4 \mathrm{~h}} \frac{\mathrm{h} 4 \mathrm{~h} 6 \mathrm{~h} 8 \mathrm{~h}}{0 \mathrm{~h}}$
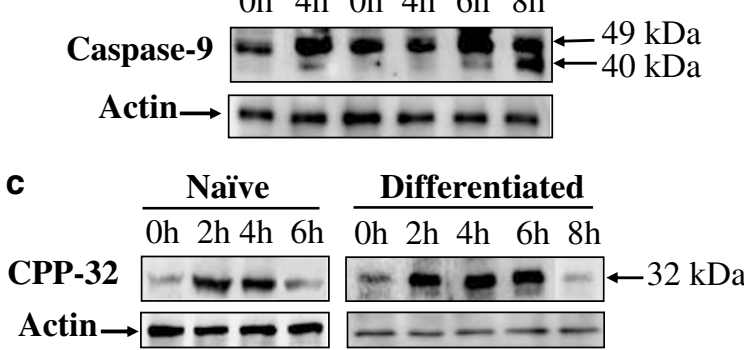

Figure 10 Attenuation of TBH-induced apoptosis in dPC12 cells by caspase- 9 inhibitor and activation kinetics of caspase-9 and -3. (a) dPC12 cells were treated with $100 \mu \mathrm{M}$ TBH for $24 \mathrm{~h}$ in the absence $(-\mathrm{In})$ or presence of the inhibitors of caspase-9 (LEHD-CHO; Casp-9 In) or caspase-8 (IETD-CHO; Casp-8 In). Cell apoptosis was determined by DAPI staining. Results are expressed as mean \pm S.E. for three separate experiments. ${ }^{*} P<0.05$ versus no $\mathrm{TBH}$ control; ${ }^{+} P<0.05$ versus TBH treatment. Cellular extracts were prepared from TBH-treated $\mathrm{nPC} 12$ and $\mathrm{dPC} 12$ cells, and subjected to Western immunoblot analyses of expression and activation of caspase-9 (b) and caspase-3 (c). For each immunoblot, the membranes were reprobed for $\beta$-actin and the results verified equal protein loading in each lane. The data are one representative of three separate immunoblots

treated cells with inhibitors of caspase- 9 or -8 , the respective initiator caspases of the mitochondria or death-receptor pathways. ${ }^{27}$ The results in Figure 10a show that dPC12 apoptosis was attenuated by inhibition of caspase- 9 , while treatment with caspase-8 inhibitor was without effect, indicating an involvement of direct mitochondrial signals. Western blot analyses of caspase- 9 expression shows that in $\mathrm{nPC} 12$ cells, expression of procaspase- $9(49 \mathrm{kDa})$ increased at $4 \mathrm{~h}$ post $-100 \mu \mathrm{M} \mathrm{TBH}$ treatment concomitant with its cleavage to a $40 \mathrm{kDa}$ product (Figure 10b). In comparison, expression of procaspase-9 did not increase until $6 \mathrm{~h}$ post-TBH exposure in $\mathrm{dPC} 12$ cells, and significant enzyme activation occurred at $8 \mathrm{~h}$ (Figure 10b). At $300 \mu \mathrm{M} \mathrm{TBH}$, procaspase-9 expression and activation occurred at $4 \mathrm{~h}$ that was temporally comparable to $\mathrm{nPC} 12$ cells treated with $100 \mu \mathrm{M} \mathrm{TBH}$ (data not shown). The activation of caspase- 3 was assessed by analysis of procaspase-3 (CPP32) cleavage. The expression of CPP32 was very low in untreated $\mathrm{dPC} 12$ cells in agreement with previous studies. ${ }^{9,10}$ Treatment with $100 \mu \mathrm{M}$ TBH resulted in the upregulation of CPP32 expression in both $\mathrm{nPC} 12$ and
dPC12 cells (Figure 10c). However, the kinetics of proenzyme cleavage and activation occurred at 6 and $8 \mathrm{~h}$ in $\mathrm{nPC} 12$ and $\mathrm{dPC} 12$ cells, respectively (Figure 10c), in a time frame similar to the activation of caspase-9 (see Figure 10b). Collectively, these results indicate a more rapid kinetics of TBH-induced activation of death caspases in nPC12 cells that would contribute to a greater vulnerability of naïve cells to TBH challenge. These results coupled to those on attenuation of TBH-induced PC12 apoptosis by caspase-9 are consistent with the hypothesis that TBH induces mitochondrial apoptotic death machinery in $\mathrm{dPC} 12$ cells.

As Apaf- 1 has been shown to be an important component of the apoptosome that participates in the caspase-9-dependent activation of caspase $-3,{ }^{27}$ we determined the expression of Apaf-1 after TBH treatment. Figure 11a shows that Apaf-1 protein expression was low from 0 to $6 \mathrm{~h}$ post-TBH and increased significantly at 8-16 $\mathrm{h}$. The enhanced expression of Apaf- 1 at $12 \mathrm{~h}$ was abrogated by NAC pretreatment (Figure $11 b)$, consistent with an involvement of cellular redox in mediating expression of the protein. The kinetics and level of Apaf-1 expression was markedly influenced by the concentration of TBH; TBH at $300 \mu \mathrm{M}$ increased Apaf- 1 at $4 \mathrm{~h}$, a time that preceded the protein expression by $8 \mathrm{~h}$ in cells treated with $100 \mu \mathrm{M}$ TBH (Figure 11a). In addition, treatment with
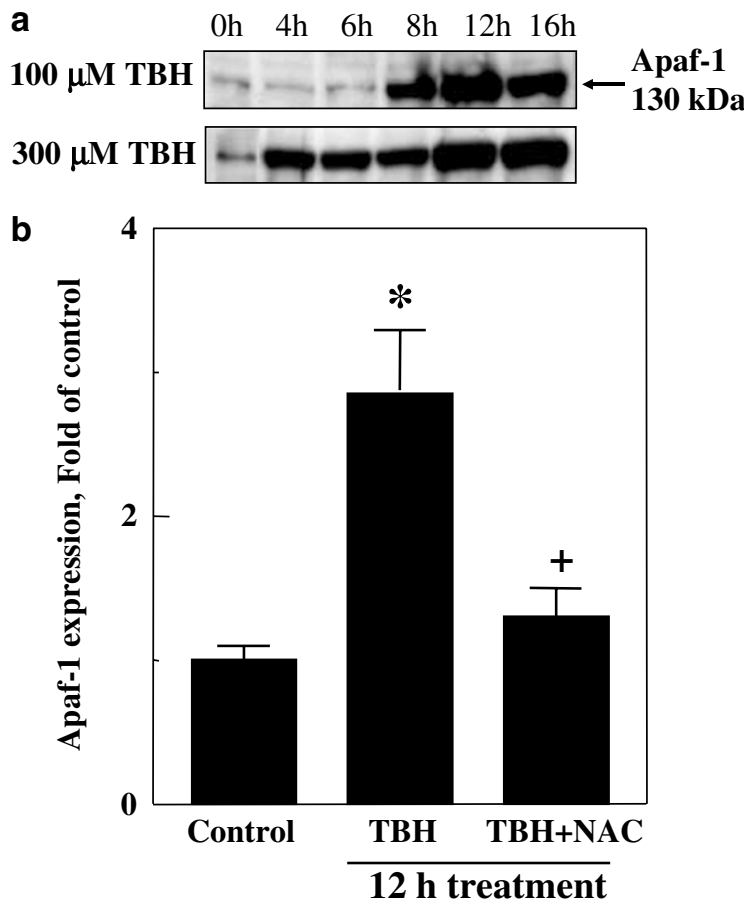

Figure 11 Effect of TBH dose on kinetics of Apaf-1 expression and the attenuation by NAC. (a) dPC12 cells were treated with 100 or $300 \mu \mathrm{M} \mathrm{TBH}$ and at various time points between 0 and $16 \mathrm{~h}$, samples were collected and cell lysates prepared for Western analyses of Apaf-1 expression. The data presented are one representative of three separate immunoblots. (b) Western analyses of Apaf-1 expression were performed in cell lysates obtained from incubations of $\mathrm{dPC} 12$ cells with $100 \mu \mathrm{M} \mathrm{TBH}$ in the absence or presence of $2 \mathrm{mM} \mathrm{NAC}$. The immunoblots were reprobed with $\beta$-actin and the expression of Apaf- 1 was normalized to $\beta$-actin. The data are presented as fold above control. Results are the mean \pm S.E. for three separate preparations. ${ }^{\star} P<0.05$ versus no TBH control; ${ }^{+} P<0.05$ versus TBH treatment 
$300 \mu \mathrm{M}$ TBH caused a two-fold greater increase in Apaf-1 expression at $16 \mathrm{~h}$ as compared to treatment with $100 \mu \mathrm{M}$ $\mathrm{TBH}$. Together, these results show that the kinetics of Apaf-1 expression is responsive to the oxidant load and the cellular redox state. Baseline Apaf-1 protein expression in $\mathrm{nPC12}$ cells was five-fold higher than dPC12 cells (data not shown), and this lower basal Apaf-1 may contribute to the decreased sensitivity of $\mathrm{dPC} 12$ cells to $\mathrm{TBH}$ challenge.

\section{Discussion}

Our current study demonstrated that at a given TBH load, nPC12 and dPC12 cells exhibit differential susceptibility in that differentiated cells were three-fold more resistant to oxidative injury. This resistance was associated with a highly reduced intracellular environment as reflected in increased cytoplasmic and mitochondrial GSH, increased GSH/GSSG ratio, elevated NADPH and NADH pools, higher activities of GSH redox enzymes and an ability to better maintain $\Delta \psi_{\mathrm{m}}$. This reducing cellular status contributed to a greater capacity for maintaining GSH redox homeostasis through enhanced pentose phosphate shunt activity and NADPH supply, increased TBH metabolism and decreased apoptotic death. Our results agree with the studies of Sung et al. ${ }^{21}$ who showed that dPC12 cells are significantly more resistant to $\mathrm{H}_{2} \mathrm{O}_{2}$ than naïve cells even under conditions where serum-free medium was used to induce PC12 differentiation. NGF treatment has been shown to enhance cellular antioxidant capacity such as expression of GSH peroxidase,${ }^{15}$ heme oxygenase- $1,{ }^{14}$ catalase $^{15}$ and GSH metabolism ${ }^{16-18}$ in PC12 cells. Studies of Vyas et al. ${ }^{20}$ further demonstrated that $\mathrm{dPC} 12$ cells exhibited less sensitivity to cytochrome $c$-induced apoptosis. Interestingly, Sasaki et al. ${ }^{23}$ demonstrated that $\mathrm{dPC} 12$ cells were more susceptible to TBH in association with a two- to threefold decrease in GSH peroxidase activity and decreased cellular GSH concentration. The differential oxidative susceptibility of $\mathrm{nPC} 12$ and $\mathrm{dPC} 12$ cells between our studies and those of Sasaki et al. may be related to differences in inducing PC12 differentiation. We grew nPC12 cells in complete growth medium (15\% serum) supplemented with NGF for a period of 8-11 days to induce cell differentiation. While Sasaki et al. ${ }^{23}$ similarly used complete media for cell growth, defined medium with a reduced percentage of horse serum $(0.5 \%)$ was used in cell differentiation; moreover, cells were treated with NGF for 5 days before experimentation. Thus, media serum concentrations and duration of NGF treatment could likely influence cell sensitivity to oxidative stress.

Our attempts to distinguish between $\mathrm{TBH}$-induced $\mathrm{PC} 12$ apoptosis and secondary necrosis using YOPRO-1/PI double staining coupled to flow cytometry proved to be problematic because of two methodological issues. First, the increased membrane leakiness and permeability caused by trypsinization resulted in an artifactually high basal apoptosis than obtained in cells on coverslips stained with DAPI. The duration it took to trypsinize dPC12 cells correlated with a more elevated basal apoptosis in these cells. McGuire et al. ${ }^{28}$ similarly detected significant basal levels of apoptosis caused by trypsinization of murine squamous cell carcinoma cells. The activation of anoikis when cells detach, particularly
dPC12 cells, ${ }^{29-31}$ could further contribute to elevated basal apoptosis. The potential interference of YO-PRO-1 fluorescence by $\mathrm{PI}$ when used in combination proved to be problematic for data analyses. PC12 cells exposed to YOPRO-1 and PI individually subscribe to their expected flow cytometry distribution (Figure $5 \mathrm{a}$ ). However, cells exposed to combined YO-PRO-1/PI led to uncharacteristic YO-PRO-1 fluorescence, which resulted in 'elliptical' flow cytometry profiles (Figure 5b) that differed from the pattern as per the manufacturer's protocol and resembled those described by McGuire et al. ${ }^{28}$ and Jerome et al. ${ }^{32}$ This atypical YO-PRO-1 fluorescence behavior is not cell type specific as Jurkat cells treated with different apoptotic stimuli (camptothecin, staurosporine or $\mathrm{TBH}$ ) yielded profiles (data not shown) similar to that generated in TBH-treated PC12 cells (Figure 5b). While these methodological limitations did not allow for unequivocal quantification of contributions of apoptosis and necrosis to $\mathrm{TBH}$-induced cell death, qualitatively, the flow cytometry analyses support our findings and conclusions obtained with DAPI staining.

Our previous results demonstrated that TBH-induced apoptosis in nPC12 cells is mediated by an early loss of GSH/GSSG redox balance caused by the oxidant ${ }^{9}$ in association with mitochondrial disruption, mitochondrial ROS production and death caspase activation. ${ }^{9,24} \mathrm{We}$ further found that an induction of GSH/GSSG imbalance per se directly initiated apoptosis in these cells without ROS involvement. ${ }^{10}$ The current results show that $\mathrm{TBH}$-induced apoptosis in dPC12 cells is similarly mediated by cellular GSH/GSSG redox, and that cellular redox play a causal role in apoptosis initiation. The kinetic data revealed an early peak GSH/GSSG redox shift $(5-15 \mathrm{~min})$ that preceded activation of Apaf-1, caspase- 9 and -3 , and apoptosis. The normalization of redox balance at $1 \mathrm{~h}$ post- $\mathrm{TBH}$ did not prevent apoptosis progression, indicating a defined window of redox signaling. The fact that NAC pretreatment blocked apoptosis, but not its addition at $1 \mathrm{~h}$ post-TBH and at a time after peak redox shift (Figure 7a), agrees with this and previous interpretation. ${ }^{24}$ Studies with diamide further showed that the induction of redox imbalance per se without ROS generation can elicit dPC12 cell apoptosis as in $\mathrm{nPC} 12$ cells, ${ }^{10}$ suggesting that loss of redox balance may, in fact, be the mechanism by which oxidants like TBH mediate cell apoptosis. Finally, studies with ethacrynic acid and elevated TBH to modulate cellular redox demonstrated that a higher percentage of cell apoptosis was linked to a larger cellular redox imbalance (Figure 8). Collectively, our results support the notion that the transition of PC12 cells from a proliferative to a differentiated, quiescent stage is associated with acquisition of a highly reduced intracellular environment, which confers cytoprotection against oxidative challenge. The reason as to why PC12 cells acquire a reduced intracellular status during differentiation is unclear. One possibility is that neuronal cells are highly oxidative, which could render cells vulnerable to ROS-induced injury. ${ }^{33}$ Therefore, adaptation of differentiated neuron-like PC12 cells to a reduced environment and a higher expression of redox enzymes would permit cells to function optimally under oxidizing conditions, and increase the likelihood for survival against oxidative challenges. 
$\mathrm{TBH}$-induced apoptosis in $\mathrm{dPC} 12$ cells was mediated by mitochondrial signaling as in nPC12 cells. ${ }^{9}$ Involvement of the mitochondrial apoptotic pathway was evidenced by specific attenuation of cell apoptosis by caspase- 9 inhibition as well as by increased Apaf-1 expression and activation of caspase- 9 and -3 , which preceded apoptosis at $24 \mathrm{~h}$. Apaf- 1 and procaspase- 9 are important components of the apoptosome that participates in the proteolytic activation of caspase-9 and downstream activation of caspase-3. ${ }^{26}$ The blockade of Apaf- 1 expression by NAC and the sensitivity of its expression kinetics to $\mathrm{TBH}$ dose are in accordance with a role for cellular redox in $\mathrm{dPC} 12$ apoptosis.

In summary, we have shown that differentiation of PC12 cells from a naïve and proliferative phenotype afforded cytoprotection against oxidative challenge. This decreased $\mathrm{dPC} 12$ vulnerability is associated with an adapted increase in cellular reductant pools (GSH, NADPH) and a higher ability to maintain GSH homeostasis through increased redox cycle enzyme activities and enhanced peroxide reduction. Our results further demonstrated that an early induction of GSH/ GSSG redox imbalance is important for apoptosis initiation that involves mitochondrial signaling and Apaf-1 expression. The collective findings from our current and previous study underscore the significance of cell stages (i.e. naïve versus differentiated) in determining $\mathrm{PC} 12$ cell susceptibility to oxidative challenge and the importance of redox control in apoptotic cell death. Similar studies in the future in an another cell line such as TrkA-positive neuroblastoma cell line that is sensitive to NGF-induced differentiation will determine whether cell stage and redox control are general paradigms of oxidative neuronal vulnerability.

\section{Materials and Methods}

\section{Materials}

The following chemicals were obtained from Sigma Chemicals (St Louis, MO, USA): TBH, diamide, NAC, EA, DAPI, paraformaldehyde, 2,4dinitrofluorebenzene, iodoacetic acid, glutathione (GSH and GSSG), glucose-6-phosphate dehydrogenase, GSH peroxidase, GSSG reductase, NADPH, NADH, NADP and JC-1 dye. Vybrant Apoptosis Assay Kit \#4 (V-13243, containing YO-PRO-1 and PI dyes) was purchased from Molecular Probes (Eugene, OR, USA). Inhibitors of caspase-9 (LEHD$\mathrm{CHO}$ ([acetyl-alanine-alanine-valine-alanine-leucine-leucine-proline-alaninevaline-leucine-leucine-alanine-leucine-leucine-alanine-proline-leucinehistidine-aspartate-CHO])) and caspase-8 (IETD-CHO ([acetyl-alanine-alanine-valine-alanine-leucine-leucine-proline-alanine-valine-leucineleucine-alanine-leucine-leucine-alanine-proline-isoleucine-glutamatethreonine-aspartate-CHO])) were from Calbiochem (San Diego, CA, USA). Fetal bovine serum was obtained from Atlanta Biologicals (Norcross, GA, USA). Horse serum was obtained from JRH Biosciences (Lenexa, KS, USA). F12 K (Kaighn's modification of Ham's F-12) medium was obtained from ATCC (Grand Isle, NY, USA). Penicillin-streptomycin solution and trypsin-EDTA were obtained from Gibco (Grand Island, NY, USA). Mouse NGF 2.5S (grade II) was obtained from Roche Diagnostics, $\mathrm{GmbH}$ (Mannheim, Germany). The monoclonal antibody against Apaf-1 was obtained from Affinity BioReagents (Golden, CO, USA). Monoclonal antibodies against caspase-3 (CPP32) and caspase- 9 were obtained from BD Biosciences (Bedford, MA, USA). The enhanced chemiluminescence system for Western immunoblot, hyperfilm, and secondary IgG anti-mouse and anti-rabbit antibodies were purchased from Amersham (Arlington Heights, IL, USA). Nitrocellulose membranes and BioRad protein dye assay kit were acquired from BIORAD Corporation (Hercules, CA, USA). Fluorescent mounting media were obtained from DAKO Corporation (Carpinteria, CA, USA). $12 \mathrm{~mm}$ circle number 1 Biocoat $^{\mathrm{TM}}$ poly-L-lysinecoated glass coverslips used for DAPI staining were procured from BD Biosciences (Bedford, MA, USA). All other chemicals were of reagent grade and were purchased locally.

\section{Cell culture and incubations}

PC12 were purchased from ATCC (Manassas, VA, USA). PC12 cells were cultured in $\mathrm{F} 12 \mathrm{~K}$ media with $10 \%$ heat-inactivated horse serum, $5 \%$ heatinactivated fetal bovine serum, penicillin $(100 \mathrm{U} / \mathrm{ml})$, streptomycin $(100 \mu \mathrm{g} /$ $\mathrm{ml}$ ) and $2 \mathrm{mM}$ glutamine at $37^{\circ} \mathrm{C}$ in a $95 \%$ air $/ 5 \% \quad \mathrm{CO}_{2}$ humidified environment. The culture medium was changed every 2 days. For experiments with $\mathrm{nPC12}$ cells, cells were plated in $\mathrm{F} 12 \mathrm{~K}$ media a $\mathrm{a}$ specified density (see below) the day before the experiment was performed. In studies with $\mathrm{dPC} 12$, cells were initially seeded at a density of $3 \times 10^{6}$ cells per T-75 cultured flasks in F12 $\mathrm{K}$ media and induced to differentiate with $75 \mathrm{ng} / \mathrm{ml}$ mouse NGF $2.5 \mathrm{~S}$ (grade II) for 6-8 days (priming). These primed differentiated cells were trypsinized and reseeded at specified density (see below) and grown for an additional 2-3 days in the presence of NGF. On the day of the experiment, the culture media for both $\mathrm{nPC1}$ and $\mathrm{dPC} 12$ cells were replaced with fresh $\mathrm{F} 12 \mathrm{~K}$ media (the

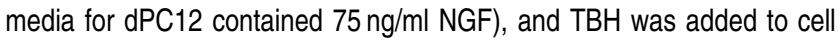
cultures at the final concentrations of 100 or $300 \mu \mathrm{M}$. Experiments with diamide were performed using a final concentration of $200 \mu \mathrm{M}$, a dose that we previously demonstrated not to induce ROS production. ${ }^{10}$ Whenever present, EA or NAC were added to cell cultures at final concentrations of $20 \mu \mathrm{M}$ or $2 \mathrm{mM}$, respectively. Caspase- 9 and -8 inhibitors were each prepared as $20 \mathrm{mM}$ stock solutions in DMSO, and were added to cell cultures at final concentrations of $10 \mu \mathrm{M}$.

\section{Detection of apoptosis by DAPI staining}

DAPI staining was performed according to the method of Wang et al..$^{34}$ Briefly, $1 \times 10^{5} \mathrm{PC} 12$ cells were grown on $12 \mathrm{~mm}$ circular poly-L-lysinecoated glass cover slips in 24-well plates. Cells were treated with 100 or $300 \mu \mathrm{M} \mathrm{TBH}$ for $24 \mathrm{~h}$, washed with phosphate-buffered saline (PBS) and fixed with cold $2 \%$ paraformaldehyde for $15 \mathrm{~min}$. Cells were then washed with PBS, fixed with cold $70 \%$ ethanol at $-20^{\circ} \mathrm{C}$ for $1 \mathrm{~h}$ and stained with $1 \mu \mathrm{g} / \mathrm{ml}$ DAPI for $30 \mathrm{~min}$ in the dark. The coverslips were washed twice with PBS, and mounted using DAKO fluorescent mounting fluid onto microscope slides. Cells were viewed and counted using a fluorescent Olympus Bx50 microscope with the $\times 40$ objective. At least six fields of total and apoptotic cells were counted on each slide, and typically, 100300 cells were counted in each field.

\section{Measurements of GSH and GSSG}

Cellular GSH and GSSG contents were determined by high-performance liquid chromatography (HPLC) ${ }^{35} \mathrm{PC} 12$ cells $\left(1 \times 10^{6}\right)$ were cultured in $60 \mathrm{~mm}$ culture plates and exposed to TBH in $5 \mathrm{ml} \mathrm{F} 12 \mathrm{~K}$ media. At time points ranging from 0 to $2 \mathrm{~h}$, cells were washed with PBS and harvested by scraping in ice-cold $5 \%$ trichloroacetic acid (TCA). The cell suspensions were centrifuged to remove TCA-insoluble proteins. In some experiments, GSH and GSSG contents were determined in the cytoplasmic and mitochondrial compartments. Cells $\left(2 \times 10^{6}\right)$ were subjected to a digitonin fractionation procedure ${ }^{36}$ to achieve separation of the cytosolic and 
mitochondrial fractions, which were treated with 5\% TCA to remove proteins. In all determinations, the acid supernatants were derivatized with $6 \mathrm{mM}$ iodoacetic acid and 1\% 2,4-dinitrophenyl fluorobenzene to yield the S-carboxymethyl and 2,4-dinitrophenyl derivatives of GSH and GSSG, respectively. Separation of GSH and GSSG derivatives was performed on a $250 \mathrm{~mm} \times 4.6 \mathrm{~mm}$ Alltech Lichrosorb NH2 10 micron column. Cellular GSH and GSSG contents were quantified by comparison to standards derivatized in the same manner.

\section{Determination of enzyme activities and TBH elimination}

Cellular enzyme activities were determined spectrophotometrically using previously established assays for glucose 6-phosphate dehydrogenase, ${ }^{37}$ GSH peroxidase ${ }^{38}$ and GSSG reductase. ${ }^{39}$ Briefly, $4 \times 10^{6}$ cells were cultured in $100 \mathrm{~mm}$ culture plates and were collected by scraping, washed and resuspended in $0.4 \mathrm{ml}$ of PBS. Cell suspensions were sonicated on ice for $2 \mathrm{~min}$ with $30 \mathrm{~s}$ intervals and centrifuged at 5000 r.p.m. for $5 \mathrm{~min}$ at $4^{\circ} \mathrm{C}$. Aliquots of cell extracts $(100 \mu \mathrm{l})$ were used for enzyme assays. In each instance, the change in NADPH was monitored at $340 \mathrm{~nm}$ and quantified using 6.22 as the millimolar extinction coefficient for NADPH. ${ }^{40}$ TBH elimination was determined as the loss of the oxidant in the incubation media with time. Cells $\left(2 \times 10^{6}\right)$ were incubated with $100 \mu \mathrm{M}$ TBH in $5 \mathrm{ml}$ serum-free FK12 media in $60 \mathrm{~mm}$ culture dishes, and at times $0,5,15$ and $30 \mathrm{~min}$, samples of media were removed for spectrophotometric determination of $\mathrm{TBH}^{41}$

\section{Measurements of NADPH and NADH}

Cell extracts $\left(4 \times 10^{6}\right.$ cells $\left./ \mathrm{ml}\right)$ were prepared and NADPH and NADH concentrations were measured according to Zhang et al. ${ }^{42}$ Cells were collected by scraping, washed twice with PBS and resuspended in $0.3 \mathrm{ml}$ of extraction buffer ( $0.1 \mathrm{M}$ Tris- $\mathrm{HCl}$, pH 8.0, $0.01 \mathrm{M}$ EDTA, $05 \%$ (v/v) Triton $\mathrm{X}$-100). Cell suspensions were sonicated in $1.5 \mathrm{ml}$ Eppendorf tubes on ice for 2 min with 30 s intervals and centrifuged at 5000 r.p.m. for $5 \mathrm{~min}$ at $4^{\circ} \mathrm{C}$. The supernatants were collected and immediately analyzed for NADPH. Aliquots $(100 \mu \mathrm{l})$ of cell extracts (representing total NADPH and NADH) in a volume of $1 \mathrm{ml}$ were read spectrophotometrically at $340 \mathrm{~nm}$ (A1). Similar aliquot samples $(100 \mu \mathrm{l})$ were incubated in reaction mixtures containing $0.1 \mathrm{M}$ phosphate buffer, $\mathrm{pH} 7.6,0.05 \mathrm{M}$ GSSG and 5 IU GSSG reductase, at $25^{\circ} \mathrm{C}$ for $5 \mathrm{~min}$ to convert NADPH to $\mathrm{NADP}^{+}$(A2). The difference in absorbance between the two readings (A1-A2) and the A2 absorbance represented the amount of NADPH and NADH in the sample, respectively. Cellular NADPH and NADH were quantified by comparison to standards.

\section{Flow cytometry analyses}

The changes in mitochondrial membrane potential, $\Delta \psi_{\mathrm{m}}$, were detected by flow cytometry using the fluorescent cationic dye, JC-1. In control cells, an intact $\Delta \psi_{\mathrm{m}}$ allows $\mathrm{JC}-1$, bearing a delocalized positive charge, to accumulate and aggregate in the mitochondrial matrix, where it fluoresces red. In apoptotic cells, the collapse of $\Delta \psi_{\mathrm{m}}$ causes JC- 1 to remain in the cytoplasm in a green fluorescent monomeric form. Therefore, mitochondrial depolarization can be detected by a decrease in the red-to-green fluorescence intensity ratio, that is, fluorescence emission shift from red $(590 \mathrm{~nm})$ to green $(525 \mathrm{~nm})$. Apoptotic cells, as characterized by decreased $\Delta \psi_{\mathrm{m}}$, exhibited low red-to-fluorescence ratio. $\mathrm{nPC} 12$ and $\mathrm{dPC} 12$ cells were treated with $100 \mu \mathrm{M} \mathrm{TBH}$ for $30 \mathrm{~min}$ and $1 \mathrm{~h}$. Cells were collected and incubated with $5 \mu \mathrm{g} / \mathrm{ml}$ of $\mathrm{JC}-1$ at $37^{\circ} \mathrm{C}$ in a $5 \% \mathrm{CO}_{2}$ incubator for $15 \mathrm{~min}$. After washing, cells were analyzed on a FACS Calibur flow cytometer (Becton Dickinson, San Jose, CA, USA).
Quantification of apoptosis and necrosis was assessed using YOPRO1/PI double staining to study multiple cell death-associated parameters simultaneously according to the manufacturer's protocol (Vybrant Apoptosis Assay Kit \#4, Molecular Probes, Eugene, OR, USA). TBHtreated cells were harvested and washed, and resuspended in cold PBS with suggested dilutions of YOPRO-1 and PI dyes. Cells were incubated for $30 \mathrm{~min}$ on ice and then analyzed by flow cytometry (FACS Calibur; Becton Dickinson, San Jose, CA, USA) using $488 \mathrm{~nm}$ excitation and measuring fluorescence emission at $530 \mathrm{~nm}$ (FL1) and $575 \mathrm{~nm}$ (FL3). As a positive control for apoptosis, PC12 cells were treated with $0.5 \mu \mathrm{M}$ staurosporine, which induces cell death exclusively by apoptosis. ${ }^{26}$ Viable cells exclude both dyes and are YO-PRO-1 ${ }^{-} / \mathrm{PI}^{-}$. Cells in early apoptosis showed increased permeability to YO-PRO-1 and remained impermeable to $\mathrm{PI}\left(\mathrm{YO}-\mathrm{PRO}-1^{+} / \mathrm{PI}^{-}\right)$, while cells in late phase apoptosis or those undergoing secondary necrosis are permeable to both YO-PRO-1 and $\mathrm{PI}$ $\left(\mathrm{YO}-\mathrm{PRO}-1^{+} / \mathrm{PI}^{+}\right)$.

\section{Preparation of cell lysates for Western analyses}

\section{Lysate preparation}

PC12 cells $\left(2 \times 10^{6}\right)$ were plated in T-25 culture dishes and treated with 100 or $300 \mu \mathrm{M} \mathrm{TBH}$ for specified times from 0 to $16 \mathrm{~h}$. Thereafter, cells were ruptured with $600 \mu$ l of lysis buffer containing $300 \mathrm{mM} \mathrm{NaCl}, 50 \mathrm{mM}$ Tris- $\mathrm{HCl}, 0.5 \%$ Triton X-100, $10 \mu \mathrm{g} / \mathrm{ml}$ leupeptin, $10 \mu \mathrm{g} / \mathrm{ml}$ aprotinin, $1 \mathrm{mM}$ phenylmethylsulfonylfluoride and $1.8 \mathrm{mg} / \mathrm{ml}$ iodoacetamide for $30 \mathrm{~min}$ at $4^{\circ} \mathrm{C}$. Cells were scraped and cell extracts stored at $-20^{\circ} \mathrm{C}$ until later use in Western analyses.

\section{Western analyses}

Protein $(20 \mu \mathrm{g})$ was resolved on $8 \%$ acrylamide gels (100 V, $120 \mathrm{~min})$ for Apaf- 1 or on $12 \%$ acrylamide gels ( $100 \mathrm{~V}, 180 \mathrm{~min})$ for caspase- 3 and -9 , and blotted onto nitrocellulose membranes (Apaf-1) or PVDF membranes (caspase-3 and -9 ). The membranes were individually probed with antiApaf-1 $(1: 1000 ; 3 \mathrm{~h})$, or with anti-CPP32 $(1: 250 ; 3 \mathrm{~h})$ or anti-caspase-9 $(1: 250 ; 3 \mathrm{~h})$ antibodies. The secondary antibody corresponded to the primary antibody (rabbit or mouse) and was conjugated to horseradish peroxidase. Detection of chemiluminescence was performed with an ECL Western blotting detection reagent according to the manufacturer's recommendations. After exposure to one antibody, each membrane was stripped (6.25 mM Tris, pH 6.7, 2\% SDS and $100 \mathrm{mM}$ mercaptoethanol) and probed again for $\beta$-actin to verify equal protein loading in each lane.

\section{Protein assay}

Protein was measured using Bio-Rad Protein Assay kit (Bio-Rad Laboratories, Hercules, CA, USA) according to the manufacturer's protocol.

\section{Statistical analysis}

Results are expressed as mean \pm S.E. Data were analyzed using a oneway ANOVA with Bonferroni corrections for multiple comparisons or using Student's $t$-test. $P$-values of $<0.05$ were considered as statistically significant.

\section{Acknowledgements}

We gratefully acknowledge Deborah Chervenak and Dr. Robert Chervenak for their assistance with flow cytometry, and Laura Coe for 
technical support. This study was supported by Grant DK 44510 from the National Institutes of Health.

\section{References}

1. Aw TY (1999) Molecular and cellular responses to oxidative stress and changes in oxidation-reduction imbalance in the intestine. Am. J. Clin. Nutr. 70: $557-565$

2. Aw TY (2003) Cellular redox: a modulator of intestinal epithelial cell proliferation. News Physiol. Sci. 18: 201-204

3. Wang TG, Gotoh Y, Jennings MH, Rhoads CA and Aw TY (2000) Lipid hydroperoxide-induced apoptosis in human colonic $\mathrm{CaCo}-2$ cells is associated with an early loss of cellular redox balance. FASEB J. 14: 1567-1576

4. Iwakiri R, Gotoh Y, Noda T, Sugihara H, Fujimoto K, Fuseler J and Aw TY (2001) Programmed cell death in rat intestine: effect of feeding and fasting. Scand. J. Gastroenterol. 36: 39-47

5. Noda T, Iwakiri R, Fujimoto K and Aw TY (2001) Induction of mild intracellular redox imbalance inhibits proliferation of CaCo-2 cells. FASEB J. 15: 21312139

6. Gotoh Y, Noda T, Iwakiri R, Fujimoto K, Rhoads CA and Aw TY (2002) Lipid peroxide-induced redox imbalance differentially mediates $\mathrm{CaCo}-2$ cell proliferation and growth arrest. Cell Prolif. 35: 221-235

7. Noda T, Iwakiri R, Fujimoto K, Rhoads CA and Aw TY (2002) Exogenous cysteine and cystine promote cell proliferation in CaCo-2 cells. Cell Prolif. 35 $117-129$

8. Tsunada S, Iwakiri R, Noda T, Fujimoto K, Fuseler J, Rhoads CA and Aw TY (2003) Chronic exposure to subtoxic levels of peroxidized lipids suppresses mucosal cell turnover in rat small intestine and reversal by glutathione. Dig. Dis. Sci. 48: 210-222

9. Pias EK and Aw TY (2002) Early redox imbalance mediates hydroperoxideinduced apoptosis in mitotic competent undifferentiated PC-12 cells. Cell Death Differ. 9: 1007-1016

10. Pias EK and Aw TY (2002) Apoptosis in mitotic competent undifferentiated cells is induced by cellular redox imbalance independent of reactive oxygen species production. FASEB J. 16: 781-790

11. Greene LA and Tischler AS (1976) Establishment of a noradrenergic clonal line of rat adrenal pheochromocytoma cells which respond to nerve growth factor Proc. Natl. Acad. Sci. USA 73: 2424-2428

12. Kamata $H$, Tanaka $C$, Yagisawa $H$ and Hirata $H$ (1996) Nerve growth factor and forskolin prevent $\mathrm{H} 2 \mathrm{O} 2$-induced apoptosis in $\mathrm{PC} 12$ cells by glutathione independent mechanism. Neurosci. Lett. 212: 179-182

13. Haviv R and Stein R (1999) Nerve growth factor inhibits apoptosis induced by tumor necrosis factor in PC12 cells. J. Neurosci. Res. 55: 269-277

14. Liu H, Nowak R, Chao W and Bloch KD (2003) Nerve growth factor induces anti-apoptotic heme oxygenase-1 in rat pheochromocytoma PC12 cells. J. Neurochem. 86: 1553-1563

15. Sampath D, Jackson GR, Werrbach-Perez K and Perez-Polo JR (1994) Effects of nerve growth factor on glutathione peroxidase and catalase in PC12 cells. J. Neurochem. 62: 2476-2479

16. Pan Z and Perez-Polo R (1993) Role of nerve growth factor in oxidant homeostasis: glutathione metabolism. J. Neurochem. 61: 1713-1721

17. Pan Z and Perez-Polo R (1996) Increased uptake of L-cysteine and L-cystine by nerve growth factor in rat pheochromocytoma cells. Brain Res. 740 : 21-26

18. Pan Z and Perez-Polo R (1996) Regulation of gamma-glutamylcysteine synthetase activity by nerve growth factor. Int. J. Dev. Neurosci. 14: 559-566

19. Shimoke K, Amano H, Kishi S, Uchida H, Kudo M and Ikeuchi T (2004) Nerve growth factor attenuates endoplasmic reticulum stress-mediated apoptosis via suppression of caspase-12 activity. J. Biochem. (Tokyo) 135: 439-446

20. Vyas $S$, Juin $P$, Hancock D, Suzuki $Y$, Takahashi $R$, Triller A and Evan G. (2004) Differentiation-dependent sensitivity to apoptogenic factors in PC12 cells. J. Biol. Chem. 279: 30983-30993
21. Sung YJ, Cheng CL, Chen CS, Huang HB, Huang FL, Wu PC, Shiao MS and Tsay HJ (2003) Distinct mechanisms account for beta-amyloid toxicity in PC12 and differentiated PC12 neuronal cells. J. Biomed. Sci. 10: 379-388

22. Mielke $\mathrm{K}$ and Herdegen $\mathrm{T}$ (2002) Fatal shift of signal transduction is an integral part of neuronal differentiation: JNKs realize TNFalpha-mediated apoptosis in neuronlike, but not naive, PC12 cells. Mol. Cell. Neurosci. 20: 211-224

23. Sasaki N, Baba N and Matsuo M (2001) Cytotoxicity of reactive oxygen species and related agents toward undifferentiated and differentiated rat phenochromocytoma PC12 cells. Biol. Pharm. Bull. 24: 515-519

24. Pias EK, Ekshyyan OY, Rhoads CA, Fuseler J, Harrison L and Aw TY (2003) Differential effects of superoxide dismutase isoform expression on hydroperoxide-induced apoptosis in PC-12 cells. J. Biol. Chem. 278: 1329413301

25. Gendron MC, Schrantz N, Metivier D, Kroemer G, Maciorowska Z, Sureau F, Koester S and Petit PX (2001) Oxidation of pyridine nucleotides during Fasand ceramide-induced apoptosis in Jurkat cells: correlation with changes in mitochondria, glutathione depletion, intracellular acidification and caspase 3 activation. Biochem. J. 353: 357-367

26. Kruman I, Guo Q and Mattson MP (1998) Calcium and reactive oxygen species mediate staurosporine-induced mitochondrial dysfunction and apoptosis in PC12 cells. J. Neurosci. Res. 51: 293-308

27. Pias EK and Aw TY (2003) Mechanisms of parenchymal apoptosis In Molecular Basis of Microcirculatory Disorders Schmid-Schonbein GW, Granger DN (eds) (Springer: Verlag) pp. 297-309

28. McGuire TF, Trump DL and Johnson CS. (2001) Vitamin D(3)-induced apoptosis of murine squamous cell carcinoma cells. Selective induction of caspase-dependent MEK cleavage and up-regulation of MEKK-1. J. Biol. Chem. 276: 26365-26373

29. Hong JH, Noh KM, Yoo YE, Choi SY, Park SY, Kim YH and Chung JM (2003) Iron promotes the survival and neurite extension of serum-starved PC12 cells in the presence of NGF by enhancing cell attachment. Mol. Cells 15: 10-19

30. Kwon M, Seo S, Chun H, Chung JM, Chung IK and Hur KC (2002) Dual effect of nerve growth factor on cell death of $\mathrm{PC} 12$ cells Induced by serum deprivation. Mol. Cells 13: 167-174

31. Grossmann J (2002) Molecular mechanisms of 'detachment-induced apoptosis - Anoikis'. Apoptosis 7: 247-260

32. Jerome KR, Chen Z, Lang R, Torres MR, Hofmeister J, Smith S, Fox R, Froelich CJ and Corey L. (2001) HSV and glycoprotein J inhibit caspase activation and apoptosis induced by granzyme B or Fas. J. Immunol. 167: 3928-3935

33. Halliwell B and Gutteridge JM (1985) The importance of free radicals and catalytic metal ions in human diseases. Mol. Aspects Med. 8: 89-193

34. Wang X, Martindale JL, Liu Y and Holbrook NJ (1998) The cellular response to oxidative stress: influences of mitogen-activated protein kinase signalling pathways on cell survival. Biochem. J. 333: 291-300

35. Reed DJ, Babson JR, Beatty PW, Brodie AE, Ellis WW and Potter DW (1980) Anal. Biochem. 106: 55-62

36. Andersson BS and Jones DP (1985) Use of digitonin fractionation to determine mitochondrial transmembrane ion distribution in cells during anoxia. Anal. Biochem. 146: 164-172

37. Deutsch J (1983) Glucose-6-phosphate dehydrogenase In Methods of Enzymatic Analysis Vol 3, 3rd edn, Bergmeyer HU, Bergmeyer J, Crabl M (eds) (Weinheim: Verlag Chemie) pp. 190-195

38. Paglia DE and Valentine WN (1967) Studies on the quantitative and qualitative characterization of erythrocyte glutathione peroxidase. J. Lab. Clin. Med. 70: 158-169

39. Goldberg DM and Spooner RJ (1983) Glutathione reductase In Methods of Enzymatic Analysis Vol 3, 3rd edn, Bergmeyer HU, Bergmeyer J, Crabl M (eds) (Weinheim: Verlag Chemie) pp. 258-264

40. Jones DP (1981) Determination of pyridine dinucleotides in cell extracts by high-performance liquid chromatography. J. Chromatogr. 225: 446-449

41. Heath RL and Tappel AL (1976) A new sensitive assay for the measurement of hydroperoxides. Anal. Biochem. 76: 184-191

42. Zhang Z, Yu J and Stanton RC (2000) A method for determination of pyridine nucleotides using a single extract. Anal. Biochem. 285: 163-167 